\title{
Erratum to machine perfusion of donor heart with normothermic blood versus hypothermic HTK in preserving coronary endothelium in a porcine model of DCD
}

\section{Editorial Office}

Annals of Palliative Medicine

Correspondence to: Editorial Office. Annals of Palliative Medicine. Email: apm@amepc.org.

doi: 10.21037/apm-2021-04

View this article at: http://dx.doi.org/10.21037/apm-2021-04

Erratum to: Ann Palliat Med 2020;9:1476-87.

This article (1) that appeared on Page: 1476-1487, Vol 9, No 4 (July 2020) Issue of the Annals of Palliative Medicine (APM) (1), unfortunately contained a mistake as three authors were missing in the Author list, Academic affiliation, and Contributions. The corrected version of Author list, Academic affiliation, and Contributions is presented below:

Pengyu Zhou ${ }^{1 \#}$, Ximao Liu ${ }^{1 \#}$, Sevil Korkmaz-Icöz ${ }^{2}$, Lars Saemann ${ }^{2,3}$, Zezhou Xiao ${ }^{1}$, Rongning Xu ${ }^{1}$, Xuefeng Lin ${ }^{1}$, Peng Zhu ${ }^{1}$, Jun $\mathrm{Lu}^{1}$, Gábor Szabó ${ }^{2,3}$, Shaoyi Zheng ${ }^{1}$

${ }^{1}$ Department of Cardiovascular Surgery, Nanfang Hospital, Southern Medical University, Guangzhou, China; ${ }^{2}$ Department of Cardiac Surgery, Heidelberg University Hospital, Heidelberg, Germany; ${ }^{3}$ Department of Cardiac Surgery, University Hospital Halle (Saale), Halle, Germany

Contributions: (I) Conception and design: P Zhou, L Saemann, S Korkmaz-Icöz, G Szabó, S Zheng; (II) Administrative support: P Zhu, J Lu, G Szabó, S Zheng; (III) Provision of study materials or patients: J Lu, G Szabó, S Zheng; (IV) Collection and assembly of data: X Liu, Z Xiao, R Xu, X Lin; (V) Data analysis and interpretation: P Zhou, X Liu; (VI) Manuscript writing: All authors; (VII) Final approval of manuscript: All authors.

"These authors contributed equally to this work.

Correspondence to: Prof. Shaoyi Zheng. Department of Cardiovascular Surgery, Nanfang Hospital, Southern Medical University, Guangzhou, China. Email: shaoyizheng@yahoo.com; Prof. Dr. med. Gábor Szabó. Department of Cardiac Surgery, University Hospital Halle (Saale), Halle, Germany. Email: gabor.szabo@uk-halle.de.

Click here to view the updated version of the article.

Open Access Statement: This is an Open Access article distributed in accordance with the Creative Commons AttributionNonCommercial-NoDerivs 4.0 International License (CC BY-NC-ND 4.0), which permits the non-commercial replication and distribution of the article with the strict proviso that no changes or edits are made and the original work is properly cited (including links to both the formal publication through the relevant DOI and the license). See: https://creativecommons.org/licenses/by-nc$\mathrm{nd} / 4.0 \%$. 


\section{References}

1. Zhou P, Liu X, Xiao Z, et al. Machine perfusion of donor heart with normothermic blood versus hypothermic HTK in preserving coronary endothelium in a porcine model of DCD. Ann Palliat Med 2020;9:1476-87.

Cite this article as: Editorial Office. Erratum to machine perfusion of donor heart with normothermic blood versus hypothermic HTK in preserving coronary endothelium in a porcine model of DCD. Ann Palliat Med 2021;10(6):71517152. doi: 10.21037/apm-2021-04 